\title{
IMPLEMENTASI MODEL PEMBELAJARAN \\ BERBASIS KOMPUTER \\ UNTUK MENINGKATKAN KOMPETENSI \\ SISWA PADA MATA PELAJARAN \\ MATEMATIKA DI SMK *
}

Oleh: Rusman **

\section{Abstrak}

Dari hasil penelitian dapat disimpulkan bahwa: (1) kondisi pembelajaran matematika di SMK yang dijadikan lokasi penelitian secara umum sudah berjalan baik, sebagaimana dapat dilihat dari: pemahaman guru matematika terhadap tujuan pembelajaran matematika, metode yang digunakan guru cukup bervariasi, meskipun materi pembelajaran matematika yang dikembangkan guru masih terlalu banyak, sumber yang digunakan guru masih menggunakan buku paket, peran siswa dalam kegiatan pembelajaran cenderung masih kurang optimal, (2) pembelajaran berbasis komputer model tutorial dan drill and practice dilaksanakan melalui tahap perencanaan, pelaksanaan dan evaluasi pembelajaran berbasis komputer. (3) faktor-faktor yang mendukung pelaksanaan model pembelajaran berbasis komputer adalah adanya laboratorium komputer yang sudah terpasang jaringan (LAN), sehingga mempermudah pelaksanaan pembelajaran berbasis komputer, sedangkan faktor yang menghambat pelaksanaan model pembelajaran berbasis komputer adalah budaya mengajar konvensional yang merasa cukup puas dengan menggunakan metode ceramah; (4). pembelajaran berbasis komputer model tutorial ternyata

*) Tulisan ini adalah hasil Penelitian Disertasi bidang kajian Teknologi Informasi Pendidikan di Universitas Pendidikan Indonesia tahun 2007

**) Dr. Rusman, S.Pd., M.Pd., adalah Sekretaris Jurusan Kurikulum dan Teknologi Pendidikan FIP Universitas Pendidikan Indonesia 
lebih efektif jika dibandingkan dengan model drill and practice pada mata pelajaran matematikat. Begitu juga jika dibandingkan antara pembelajaran berbasis komputer dengan pembelajaran konvensional yang berupa tatap muka, ternyata siswa terlihat lebih antusias dalam kegiatan pembelajaran dengan menggunakan $\mathrm{CBI}$, dibandingkan tatap muka di kelas.

Kata Kunci : Pembelajaran Berbasis Komputer

\section{A. PENDAHULUAN}

Kemampuan siswa dalam penguasaan konsep matematika masih rendah. Hasil analisis Viner, Kowith dan Beucheir (1991) bahwa kesalahan pemahaman dan penguasaan konsep matematika disebabkan beberapa hal, yaitu rekonstruksi yang salah atas bagian-bagian yang kecil, pengenalan yang salah terhadap lambang-lambang dan generalisasi yang keliru. Selain itu menurut pengalaman selama dalam pembelajaran di kelas, bahwa tingkat pemahaman siswa terhadap apa yang diketahui, ditanya dan dibahas masih rendah, akibatnya keterampilan intelektual siswa kurang berkembang.

Permasalahan yang dihadapi peserta didik adalah adanya anggapan bahwa matematika merupakan mata pelajaran abstrak yang tidak bisa diraba atau ditebak. Keabstrakan pelajaran matematika dapat dilihat dari materi yang berkenaan dengan lambang bilangan, simbol, garis, dan materi lainnya yang menekankan pada logika. Sehingga banyak diantara peserta didik yang dalam mengerjakan pelajaran matematika merasa kebingungan dan ada juga yang tidak mengerti sama sekali terhadap materi yang disampaikan guru.

Kelemahan-kelemahan yang ditunjukkan peserta didik bisa saja dapat memunculkan siswa menjadi malas, dan mungkin membenci pelajaran matematika, ditambah lagi dengan sikap dan kesan yang ditampilkan oleh guru ketika berada di depan siswa yang menunjukkan sikap yang kurang harmonis, mudah tersinggung dan sering merasa jengkel dengan pertanyaan-pertanyaan yang 
disampaikan siswa karena dianggap terus mengulang-ulang. Kejadian semacam ini mengakibatkan siswa dapat membenci pelajaran matematika yang disebabkan karena merasa kurang suka terhadap sikap guru ketika mengajar di kelas. Oleh karena itu guru tidak hanya memahami bahan materi yang akan diajarkan, tetapi hendaknya memahami semua karakteristik yang terkandung di dalamnya sehingga dapat dengan mudah menerapkan paradigma baru dalam proses pembelajaran.

Perubahan paradigma dalam pembelajaran matematika di sekolah dapat terjadi dalam empat aspek, yang menurut Ibrahim (1994: 35-37) yakni: (1) inovasi dalam struktur/materi kurikulum, (2) inovasi dalam pendekatan belajar-mengajar, (3) inovasi dalam organisasi/ manajemen kelas, (4) inovasi dalam sistem penyampaian pengajaran

Mengacu kepada pandangan di atas, maka inovasi yang dimaksud adalah berkenaan dengan sistem penyampaian pengajaran. Dimana guru dalam mengimplementasikan kurikulum dapat menggunakan berbagai model pembelajaran yang relevan dengan unit-unit pelajaran. Model pembelajaran yang diharapkan mampu mengatasi kesenjangan di atas adalah model pembelajaran berbasis komputer. Model pembelajaran ini digunakan sebagai perangkat lunak dalam sistem pembelajaran. Model Computer Based Instruction ( $\mathrm{CBI}$ ) dimanfaatkan sebagai sistem pembelajaran individual. Karena $\mathrm{CBI}$ berfungsi sebagai sistem pembelajaran individual, maka perangkat lunak (software) CBI bisa memfasilitasi belajar kepada siswa yang memanfaatkannya.

Hal ini sejalan dengan temuan Schade (Munir, 2001) bahwa daya ingat bagi orang yang membaca sendiri adalah terendah (1\%). Daya ingatan ini bisa ditingkatkan sampai $(25 \%$ - 30\%) dengan adanya bantuan alat pelajaran lain, seperti televisi yang tentunya termasuk komputer. Begitu juga hasil kajian Mathis, Smith dan Hansen (Munir, 2001: 11) mengenai sikap pelajar terhadap komputer ditemukan bahwa pelajar memiliki sikap yang positif terhadap CAL (computer aidid learning) apabila pelajar tidak mengalami kesukaran dari segi literasi komputer, tetapi sebaliknya. Hasil penelitian Kulik, Berger dan William (Munir, 2001) yang mengkaji keberkesanan 
penggunaan proses belajar berbentuk komputer terhadap 48 orang pelajar. Hasil kajiannya menunjukkan bahwa 39 orang pelajar yang menggunakan komputer memperoleh nilai yang lebih tinggi dibandingkan dengan pelajar yang menggunakan metode tradisional. Lebih lanjut dinyatakan bahwa kajian CAL memiliki keberkesanan 0,5 berbanding dengan proses belajar dengan menggunakan metoda tradisional. Penggunaan multimedia menurut Munir (2001) kalau dirancang dengan baik akan memiliki keberkesanan apabila kurikulum pembelajaran dapat dirancang secara sistemik, komunikatif dan interaktif sepanang proses pembelajaran. Berdasarkan temuan di atas, maka pengembangan model pembelajaran berbasis komputer harus mempertimbangkan prinsip-prinsip belajar, prinsip-prinsip perancangan sistem pembelajaran, dan prinsip-prinsip pembelajaran individual.

Mengacu kepada hasil temuan Schade, maka dapat dikatakan bahwa model CBI merupakan inovasi yang diduga efektif untuk meningkatkan kualitas pembelajaran dan kualitas hasil belajar matematika. Di samping menghadapi masalah pelajaran yang sulit, dalam jangka panjang pembudayaan model ini akan dapat membuat siswa belajar matematika lebih menyengkan dan mencapai hasil yang lebih optimal. Sebagaimana penelitian yang dilakukan Schade (Munir, 2001: 9) yang menemukan bahwa melalui pengajaran dengan multimedia daya ingat anak lebih meningkat sampai sebanyak $60 \%$. Oleh karena itu pemanfaatan multimedia (komputer) dalam bidang pendidikan, khususnya pembelajaran dapat dirancang dengan secara sistematik, komunikatif dan interaktif sepanjang proses pembelajaran.

Kehadiran komputer dalam proses belajar memberikan peluang kepada siswa untuk berinteraksi dengan program pembelajaran secara langsung. Oleh karena itu kehadiran komputer dalam pembelajaran sangat dirasakan kebermanfaatannya, terutama ketika merencanakan pembelajaran harus terlebih dahulu dipahami desain proses pembelajaran dengan komputer lebih terarah dan sistematis sesuai dengan tujuan pengajaran yang telah ditetapkan (Munir, 2001: 10). 
Persiapan matang sebelum mengimplementasikan sebuah pembelajaran berbasis komputer memegang peran penting demi kelancaran proses pembelajaran. Segala persiapan seperti penjadwalan sampai dengan penentuan teknis komunikasi selama proses pembelajaran merupakan tahap penting dalam melaksanakan pembelajaran berbasis komputer.

Keistimewaan-keistimewaan penggunaan komputer dalam proses pembelajaran khususnya pelajaran matematika sangat dirasakan oleh siswa. Hal ini dikarenakan siswa sudah merasa jenuh dan bosan dengan ceramah, tanya jawab, pemberian tugas dan strategi pembelajaran matematika dengan menghapal konsep dan rumus yang tidak dikaitkan dengan realitas masalah dalam kehidupan sehari-hari. Melalui komputer siswa diajak untuk berpikir kreatif dan kritis, karena mereka harus mampu menemukan sendiri jawaban persoalan yang dihadapi dengan melalui fasilitas yang ada dalam program komputer. Sebagaimana Ruseffendi (1985) menyatakan bahwa ternyata penggunaan komputer lebih sesuai dengan kehidupan sehari-hari; lebih realistik. Ini dimungkinkan karena, dengan menggunakan komputer maka bilangan-bilangan jawaban atau yang dipakai dalam perhitungan itu tidak terbatas kepada bilangan bulat dan yang kecil-kecil. Penggunaan komputer dalam pelajaran matematika akan lebih realita.

Berdasarkan paparan di atas, dipandang perlu adanya pembaharuan strategi pembelajaran matematika pada situasi dan kondisi siswa yang terjadi pada saat ini. Strategi pembelajaran matematika yang dapat dijadikan solusi adalah model pembelajaran matematika dengan berbasis komputer untuk meningkatkan kompetensi siswa.

\section{B. KERANGKA PEMIKIRAN}

\section{Teknologi Pembelajaran}

Pembelajaran yang menggunakan pendekatan sistem untuk memecahkan masalah, yaitu menerapkan rencana keseluruhan yang menyertakan berbagai unsur yang penting untuk mencapai 
tujuan yang telah ditentukan. Proses perencanaan bersistem ini disebut dengan Teknologi Pembelajaran. Proses yang dimaksud yaitu menentukan cara untuk mempelajari masalah dan kebutuhan pembelajaran, menentukan tata cara untuk pemecahannya, dan kemudian menilai hasilnya. Perancangan pembelajaran adalah tata cara yang dipakai untuk melaksanakan proses tersebut. Pengelolaan personalia, anggaran, dan penunjang untuk memperbaiki pembelajaran dalam organisasi atau lembaga disebut pengembangan pembelajaran.

Program sistem teknologis yang dipadukan dengan alat dan media pembelajaran yang dimaksud yaitu, program pembelajaran telah disusun secara terpadu antara bahan dan kegiatan pembelajaran dengan alat dan media. Tujuan dari program pembelajaran ini adalah to effect and effect learning. Titik beratnya pada dan menjelaskan bahwa belajar adalah tujuan (goal), sedangkan pembelajaran adalah suatu alat (means) untuk belajar. Jadi learning mengarah pada the relevity permanent change in person's knowledge or behavior due to experience" (Mayer, 1982).

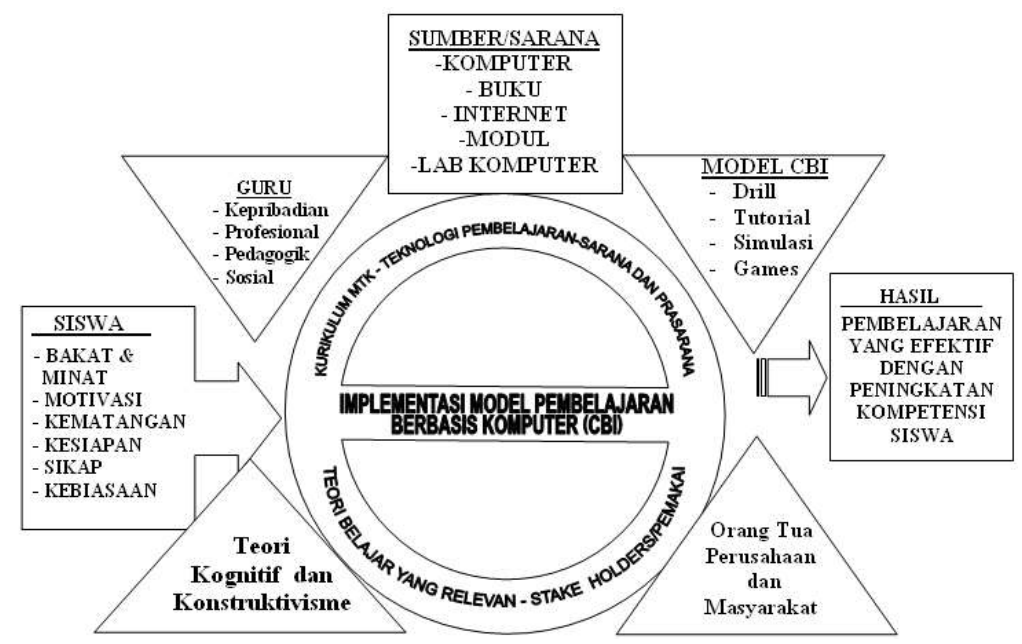

Gambar 1.

PEMETAAN TENTANG KETERKAITAN ANTAR KOMPONEN

DALAM IMPLEMENTASI MODEL PEMBELAJARAN BERBASIS KOMPUTER 


\section{Model-Model Pembelajaran Berbasis Komputer}

\section{Model Drills}

Model drills adalah suatu model dalam pembelajaran dengan jalan melatih siswa terhadap bahan pelajaran yang sudah diberikan. Melalui model drill akan ditanamkan kebiasaan tertentu dalam bentuk latihan. Dengan latihan yang terus menerus, maka akan tertanam dan kemudian akan menjadi kebiasaan. Selain itu untuk menanamkan kebiasaan, model ini juga dapat menambah kecepatan, ketetapan, kesempurnaan dalam melakukan sesuatu serta dapat pula dipakai sebagai suatu cara mengulangi bahan yang telah disajikan. juga dapat menambah kecepatan.

Model ini berasal dari model pembelajaran Herbart, yaitu model asosiasi dan ulangan tanggapan. Melalui model ini maka akan memperkuat tanggapan pelajaran pada siswa. Pelaksanaannya secara mekanis untuk mengajarkan berbagai mata pelajaran dan kecakapan, terutama pelajaran matematika yang memerlukan adanya pengulangan dan latihan yang terus menerus.

\section{Langkah-langkah Produksi Model Drills}

A. Perencanaan Produksi model Drills, meliputi:

- Satuan Pelajaran

- Perencanaan Program Drills

- Flowchart program pembelajaran Drills

B. Proses Produksi Program Drills

Setelah membuat perencanaan pengembangan program Drills langkah selanjutnya yang harus ditempuh adalah proses produksi. Di sinilah seorang programmer program pembelajaran komputer harus "mengerahkan" seluruh kemampuannya untuk menghasilkan program yang layak dimanfaatkan dalam proses pembelajaran. Pada tahap proses proses produksi program drills ini harus memperhatikan tahapan sebagai berikut: 
Introduction (pengenalan) meliputi:

1) Judul Program (title page)

2) Objektivitas Penyajian (presentation of objectif)

3) Petunjuk (Direction)

Penyajian Informasi (presentation of information), meliputi:

1) Mode Penyajian Drills

2) Panjang Teks Penyajian (length of text presentation

3) Grafik dan animasi

4) Warna dan Penggunaannya

5) Penggunaan prompt

6) Penutup (closing)

\section{Model Tutorial}

Tutorial adalah bimbingan pembelajaran dalam bentuk pemberian bimbingan, bantuan, petunjuk, arahan dan motivasi agar para siswa belajar secara efisien dan efektif. Pemberian bantuan berarti membantu siswa dalam mempelajari materi model. Petunjuk berarti memberikan julukan cara belajar secara efisien dan efektif. Arahan berarti mengarahkan para siswa untuk mencapai tujuan masing-masing. Motivasi berarti menggerakan kegiatan para siswa dalam mempelajari modul, mengerjakan tugas-tugas, dan mengikuti penilaian. Bimbingan berarti membantu para siswa memecahkan masalah-masalah belajar.

Berdasarkan uraian di atas, dapat diambil benang merahnya bahwa pembelajaran tutorial bertujuan untuk memberikan "kepuasan" atau pemahaman secara tuntas (mastery learning) kepada siswa mengenai materi/bahan pelajaran yang sedang dipelajari. Terdapat beberapa hal yang menjadi identitas dari tutorial yaitu:

- Pengenalan

- Penyajian informasi 
- Pertanyaan dan respon jawaban

- Penilaian respon

- Pemberian feedback tentang respon

- Pembetulan

- Segmen pengaturan pengajaran

- Penutup

Langkah-langkah Produksi Model Tutorial

A. Perencanaan Produksi model Drills, meliputi:

- Satuan Pelajaran (Satpel)

- Perencanaan Program Tutorial

- Flowchart program pembelajaran Tutorial

Proses Produksi Program Tutorial

Setelah membuat perencanaan pengembangan program Tutorial langkah selanjutnya yang harus ditempuh adalah proses produksi. Di sinilah seorang programmer program pembelajaran komputer harus "mengerahkan" seluruh kemampuannya untuk menghasilkan program yang layak dimanfaatkan dalam proses pembelajaran. Pada tahap proses proses produksi program tutorial ini harus memperhatikan tahapan sebagai berikut:

Introduction (pengenalan) meliputi:

1. Judul Program (title page)

2. Objektivitas Penyajian (presentation of objectif)

3. Petunjuk (Direction)

4. Stimulasi prioritas pengetahuan (stimulating prior knowledge)

5. Inisial Kontrol Siswa (Initial Student control)

Penyajian Informasi (presentation of information), meliputi:

1. Mode Penyajian atau Presentasi

2. Panjang Teks Penyajian (length of txt presentation

3. Grafik dan animasi 

4. Warna dan Penggunaannya
5. Penggunaan prompt

\section{HASIL PENELITIAN DAN PEMBAHASAN}

Pertama, kondisi pembelajaran matematika di SMK yang dijadikan lokasi penelitian secara umum sudah berjalan baik, sebagaimana dapat dilihat dari hasil penelitian yaitu: guru matematika di SMK secara umum sudah memahami tujuan yang dikembangkan dalam rencana pembelajaran. Dalam pengembangan tujuan pembelajaran sudah sesuai dengan Silabus/Kurikulum. Meskipun begitu guru masih menunjukkan kekurang optimal dalam menentukan tujuan, dikarenakan masih suka terpaku pada salah satu kemampuan siswa saja, yaitu kemampuan kognitif. Ditelaah dari metode yang digunakan guru dalam penyampaian materi pembelajaran matematika di SMK cukup bervariasi. Berbagai pendekatan konvensional dalam pembelajaran Matematika sudah dilaksanakan. Metode yang sudah dilaksanakan diantaranya adalah metode ceramah, penugasan, tanya jawab dan metode lainnya yangs esuai dengan ketentuan kurikulum.

Materi Pembelajaran matematika yang selama ini dikembangkan guru dalam kegitan pembelajaran di kelas ternyata masih terlalu banyaknya. Banyaknya beban materi yang harus disampaikan kepada siswa pada setiap semesternya membuat guru kurang begitu berperan dengan optimal. Karena itu banyak diantara guru yang masih memegang teguh buku paket yang disediakan oleh sekolah, sedangkan pengembangan melalui kompetensikompetensi yang ada di lingkungan sekolah kurang dioptimalkan.

Sumber yang digunakan guru dalam pembelajaran matematika cenderung masih tertumpu pada sumber belajar yang tersedia di sekolah (by utilization). Buku paket yang ada di sekolah dijadikan sebagai sumber utama, sedangkan penunjang yang digunakan adalah buku yang pada tahun-tahun sebelumnya digunakan. Sumber belajar masih terikat pada sumber yang tercantum di dalam 
kurikulum. Sedangkan kalau menggunakan sumber lainnya yang lebih bagus, sekolah harus harus mengeluarkan biaya yang cukup besar, sehingga terkadang guru matematika mempertimbangkan segi positif dan negatifnya dalam penggunaan sumber belajar tersebut.

Sarana yang digunakan guru dalam kegiatan pembelajaran matematika di SMK lokasi penelitian, terutama untuk menunjang pelaksanaan pembelajaran Matematika adalah tersedianya laboratorium komputer, ICT Centre, dan TV edu, dengan adanya ICT Center ini pelajaran matematika sangat terbantu terutama untuk penggunaan hardware dan software yang terkait dengan pelajaran matematika.

Peran siswa dalam kegiatan pembelajaran matematika secara umum cenderung masih kurang optimal. Aktivitas siswa dalam kegiatan pembelajaran di sekolah terutama dalam pembelajaran matematika masih suka agak gaduh. Dalam tugas-tugas pembelajaran seperti pekerjaan rumah (PR) dan tugas pembelajaran lainnya siswa sudah menyelesaikannya meskipun belum semuanya benar. Suasana kelas kalau ditinggal oleh guru terkadang langsung ribut, karena siswa-siswa banyak yang suka ikut keluar kelas.

Evaluasi yang dilakukan guru dalam pembelajaran matematika selama ini yaitu evaluasi pada setiap akhir bab (formatif) dan pada akhir semester (sumatif).

Kedua, pengembangan program pembelajaran berbasis komputer model tutorial dan dril and practice dalam meningkatkan kemampuan siswa secara umum dilakukan melalui tahap perencanaan pembelajaran, pelaksanaan pembelajaran dan evaluasi pembelajaran.

a. Perencanaan pengembangan model tutorial dan drill and practice yaitu: (1) model pembelajaran tutorial mengacu kepada komponen-komponen perencanaan pembelajaran yaitu: 
pengenalan, (b) penyajian informasi, (c) pertanyaan dan respon jawaban, (d) penilaian respon, (e) pemberian feedback tentang respon, (f) pembetulan, (g) segmen pengaturan pembelajaran, dan (h) penutup; (2) model pembelajaran drill and practice, yaitu mengacu kepada komponen pencapaian pembelajaran sebagai berikut: (a) penyajian masalah-masalah dalam bentuk latihan soal pada tingkat tertentu dari penampilan siswa; (b) siswa mengerjakan soal-soal latihan; (c) program merekam penampilan siswa, mengevaluasi kemudian memberikan umpan balik; (d) jika jawaban yang diberikan siswa benar program menyajikan materi selanjutnya, dan jika jawaban salah program menyediakan fasilitas untuk mengulangi latihan (remidial) yang dapat diberikan secara parsial atau pada akhir keseluruhan soal.

b. Pelaksanaan Pembelajaran matematika berbasis komputer pada model totorial dan drill and practice yaitu:

1) Tahap-tahap yang dilakukan dalam pelaksanaan pembelajaran model tutorial, yaitu: (a) tahap pengenalan (introduction) meliputi : (1) penampilan judul program (title page) yaitu halaman judul yang dapat menarik perhatian siswa; (2) menginformasikan tujuan pembelajaran atau kompetensi yang diharapkan (presentation of objective), meliputi standar kompetensi, kompetensi dasar dan indikator; (3) menampilkan petunjuk penggunaan (direction); (4) menampilkan stimulasi pengetahuan (stumulating prior knowledge); (5) menampilkan inisial kontrol (initial student control), yaitu berupa button pilihan untuk siswa dalam menggunakan program; (b) Tahap penyajian informasi (presentation of information) meliputi: (1) mode atau bentuk penyajian baik berupa teks, gambar, foto, image, dan sebagainya; (2) panjang teks penyajian (length of text presentation), (3) grafik dan animasi, (4) penggunaan warna, (5) penggunaan prompt; (c) tahap menampilkan pertanyaan dan respon jawaban (question of responses); (d) tahap penilaian terhadap respon/jawaban siswa (judging of responses); (e) tahap pemberian balikan terhadap respon siswa (providing feedback about responses); (f) tahap pembenaran (remediation); (g) tahap 
segmen pengaturan pengajaran (sequencing lesson segment); (h) tahap penutup (closing), biasanya berupa ringkasan atau rangkuman materi yang telah disampaikan, dan menginformasikan materi/pokok bahasan yang akan dipelajari berikutnya, program dapat pula diakhiri dengan ucapan selamat dan terima kasih.

2) Tahap-tahap yang dilakukan dalam pelaksanaan pembelajaran model drill and practice, yaitu: (a) tahap pengenalan (introduction) yaitu berupa: (1) penampilan judul program (title page) yaitu halaman judul, (2) menginformasikan tujuan pembelajaran atau kompetensi yang diharapkan (presentation of objective), (3) menampilkan petunjuk penggunaan (direction), (4) menampilkan stimulasi pengetahuan (stumulating prior knowledge), (5) menampilkan inisial kontrol (initial student control), yaitu berupa button pilihan untuk siswa dalam menggunakan program; (b) tahap penyajian informasi (presentation of information) berupa soal-soal latihan, meliputi: (1) mode atau bentuk penyajian soal, baik berupa teks, gambar, foto, image, dan sebagainya; (2) panjang teks penyajian (length of text presentation), (3) grafik dan animasi. Program drill dapat menampilkan grafik dan animasi bila dipandang perlu. (4) penggunaan warna, yaitu berhubungan dengan presentasi program baik berupa teks, grafik, gambar dan latar belakang, (5) penggunaan prompt, yaitu adanya acuan yang digunakan untuk memandu, kemana dan bagaimana program ini dilakukan dan harus bagaimana selanjutnya; (c) tahap menampilkan pertanyaan dan respon jawaban (question of responses); (d) tahap penilaian terhadap respon/jawaban siswa (judging of responses); (e) tahap pemberian balikan terhadap respon siswa (providing feedback about responses); (f) tahap pengulangan (remediation); (g) tahap pengaturan pengajaran (sequencing lesson segment); (h) tahap penutup (closing), biasanya berupa ucapan selamat telah menyesaikan program drill and practice dengan baik yang diikuti dengan perolehan skor/nilai. Bila mencapai batas 
lulus, dapat langsung keluar, tapi bila belum mencapai batas lulus, siswa harus mengulang kembali.

c. Evaluasi pembelajaran matematika berbasis komputer pada model totorial dan drill and practice yaitu dilakukan pada awal proses pembelajaran (pre test), saat proses pembelajaran dan di akhir proses pembelajaran (pos test). Hasil evaluasi pada saat proses pembelajaran menunjukkan bahwa guru masih agak kaku dan cenderung monoton dalam menyampaikan materi dalam mempraktekan program di komputer di SMK. Ditelaah dari aktivitas siswa sudah menunjukkan antusiasnya. Hanya beberapa siswa yang masih agak canggung dalam mengoperasikan program pembelajaran matematika dengan komputer. Evaluasi terhadap keberhasilan belajar siswa dilaksanakan dengan melalui post tes (tes akhir). Dari hasil evaluasi diketahui bahwa ada peningkatan kemampuan siswa antara sebelum dan sesudah melaksanakan pembelajaran berbasis komputer dengan menggunakan model tutorial dan drill and practice.

\section{1) Model Tutorial}

Peningkatan kemampuan siswa dapat dilihat dari perolehan rata-rata nilai yang diperoleh siswa setelah mengikuti kegiatan pembelajaran pada setiap tahapan pelaksanaan kegiatan pembelajaran yaitu :

\begin{tabular}{|c|c|c|c|c|c|c|c|c|c|c|c|c|c|}
\hline \multicolumn{14}{|c|}{ Paired Samples Statistics } \\
\hline & & \multicolumn{4}{|c|}{ Tahap I } & \multicolumn{4}{|c|}{ Tahap II } & \multicolumn{4}{|c|}{ Tahap III } \\
\hline & & \begin{tabular}{l} 
\} $\\
{\stackrel{\$}{ٍ}}$ & $\mathbf{z}$ & 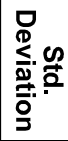 & 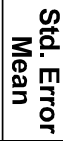 & $\begin{array}{l}3 \\
\mathbb{1} \\
\stackrel{0}{5}\end{array}$ & $\mathbf{z}$ & 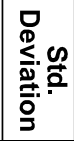 & 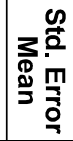 & $\begin{array}{l}3 \\
\mathbb{\$} \\
\stackrel{3}{3}\end{array}$ & $\mathbf{z}$ & 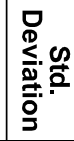 & 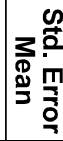 \\
\hline \multirow{2}{*}{$\begin{array}{c}\text { Pair } \\
1\end{array}$} & PRETES & 2.4000 & 40 & 1.1048 & .1747 & 2.6250 & 40 & 1.1699 & .1850 & 3,0250 & 40 & 1.0497 & .1660 \\
\hline & POSTES & 7.9000 & 40 & .7779 & .1230 & 8.1250 & 40 & .7906 & .1250 & 8.2500 & 40 & .6699 & .1059 \\
\hline
\end{tabular}
\end{tabular}

Rata-rata hasil belajar siswa SMK Negeri pada tahap I antara sebelum dilaksanakan proses pembelajaran berbasis komputer 
model tutorial yaitu sebesar 2,40 dengan standar deviasi sebesar 1,10, sedangkan rata-rata setelah dilaksanakan proses pembelajaran berbasis komputer model tutirial yaitu sebesar 7,90 dengan standar deviasi 0,78. Hasil seperti ini memberikan gambaran bahwa proses pembelajaran berbasis komputer model tutorial yang dilakukan oleh siswa menunjukkan adanya keberhasilan.

Rata-rata hasil belajar siswa SMKN pada tahap II antara sebelum dilaksanakan proses pembelajaran berbasis komputer model tutorial yaitu sebesar 2,62 dengan standar deviasi sebesar 1,17, sedangkan rata-rata sesudah dilaksanakan proses pembelajaran berbasis komputer model tutorial yaitu sebesar 8,12 dengan standar deviasi sebesar 0,79. Hasil seperti ini menggambarkan bahwa proses pembelajaran berbasis komputer model tutorial yang dilakukan oleh siswa sudah menunjukkan keberhasilan jika dilihat dari aspek perolehan nilai belajar siswa antara sebelum dilaksanakan proses pembelajaran berbasis komputer model tutorial dengan sesudah dilaksanakan proses pembelajaran berbasis komputer model tutorial.

Dari hasil perhitungan diperoleh rata-rata keberhasilan belajar siswa tahap III antara sebelum dilaksanakan proses pembelajaran berbasis komputer model tutorial yaitu sebesar 3,02 dengan standar deviasi sebesar 1,05. Sedangkan ratarata setelah pelaksanaan pembelajaran yaitu sebesar 8,25 dengan standar deviasi 0,67 . Hasil seperti ini menunjukkan bahwa kegiatan pembelajaran tahap III secara umum menunjukkan adanya peningkatan kemampuan antara sebelum dan sesudah proses pembelajaran berbasis komputer model tutorial.

Untuk melihat kebermaknaan proses pembelajaran berbasis komputer model tutorial pada setiap tahap penelitian, maka dilakukan uji perbedaan. Melalui uji perbedaan ini akan 
diketahui ada tidaknya peningkatan nilai prestasi siswa yang diperoleh antara sebelum proses pembelajaran berbasis komputer model tutorial dan sesudah proses pembelajaran berbasis komputer model tutorial. Hasil perhitungan analisis variansinya adalah sebagai berikut.

\begin{tabular}{|c|c|c|c|c|c|c|c|c|c|}
\hline \multicolumn{10}{|c|}{ Paired Samples Test } \\
\hline & & \multicolumn{5}{|c|}{ Paired Differences } & \multirow{3}{*}{$\mathbf{t}$} & \multirow{3}{*}{ df } & \multirow{3}{*}{ 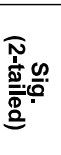 } \\
\hline & & \multirow[t]{2}{*}{$\begin{array}{l}3 \\
\mathbb{\$} \\
\Xi\end{array}$} & \multirow{2}{*}{ 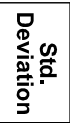 } & \multirow{2}{*}{ 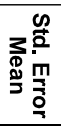 } & \multicolumn{2}{|c|}{$\begin{array}{l}95 \% \text { Confidence } \\
\text { Interval of the } \\
\text { Difference }\end{array}$} & & & \\
\hline & & & & & Lower & Upper & & & \\
\hline Tahap I & $\begin{array}{l}\text { PRETES1 - } \\
\text { POSTES1 }\end{array}$ & -5.50 & .7161 & .1132 & -5.729 & -5.271 & 48.57 & 39 &, 000 \\
\hline Tahap II & $\begin{array}{l}\text { PRETES1 - } \\
\text { POSTES1 }\end{array}$ & -5.50 & .9871 & .1561 & -5.816 & -5.184 & 35.24 & 39 &, 000 \\
\hline Tahap III & $\begin{array}{l}\text { PRETES1 - } \\
\text { POSTES1 }\end{array}$ & -5.23 & .9737 & .1540 & -5.536 & -4.914 & 33.94 & 39 &, 000 \\
\hline
\end{tabular}

Pada tahap I diketahui bahwa hasil tes awal dengan akhir menunjukkan adanya perbedaan yaitu ditunjukkan oleh $t_{\text {hitung }}$ sebesar 48,57 dengan $p<0,001$. Artinya bahwa kemampuan siswa pada mata pelajaran Matematika antara sebelum dan sesudah dilaksanakan proses pembelajaran berbasis komputer model tutorial menunjukkan adanya peningkatan yang signifikan.

Keberhasilan proses pembelajaran berbasis komputer model tutorial juga ditunjukkan oleh keberhasilan belajar siswa pada tahap II. Dari hasil analisis diketahui bahwa $t_{\text {hitung }}$ sebesar 35,24 dengan $p<0,001$. Artinya kemampuan siswa antara sebelum dan sesudah proses pembelajaran berbasis komputer model tutorial pada mata pelajaran Matematika menunjukkan adanya perbedaan.

Dari hasil perhitungan diperoleh gambaran bahwa $t_{\text {hitung }}$ sebesar 33,94 dengan $p<0,001$. Hal ini mengandung arti bahwa kemampuan siswa antara sebelum dan sesudah proses pembelajaran matematika berbasis komputer pada tahap III menunjukkan adanya perbedaan antara kemampuan awal dengan kemampuan akhir setelah mengikuti pembelajaran. 
Berdasarkan hasil analisis di atas dapat diambil benang merahnya bahwa pelaksanaan proses pembelajaran berbasis komputer model tutorial pada setiap tahapannya menunjukkan adanya keefektivan. Hal ini dapat dilihat dari adanya peningkatan pengetahuan siswa antara sebelum dan sesudah dilaksanakan proses pembelajaran berbasis komputer model tutorial pada setiap tahapan pelaksanaan pembelajaran. Peningkatan kemampuan siswa setelah implementasi pembelajaran pada setiap tahapnya dapat dilihat pada tabel berikut.

Tabel 1. Perbandingan Hasil Belajar Matematika Siswa SMKN Pada Setiap Tahap (I, II dan III) Pembelajaran Berbasis Komputer

Model Tutorial Pada Pelajaran Matematika

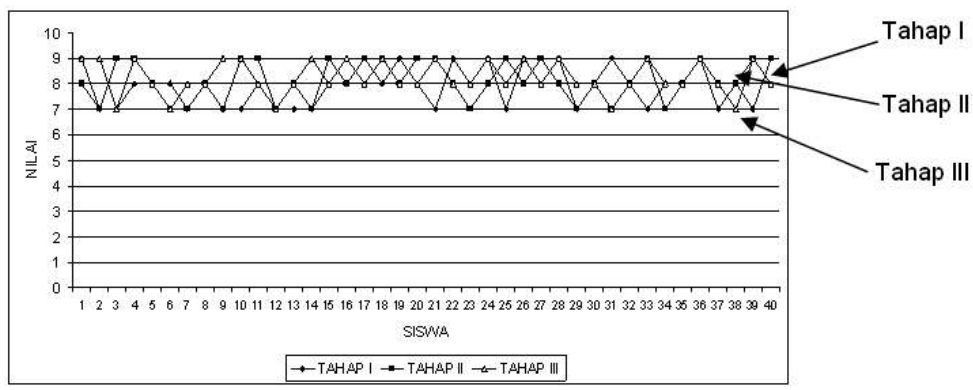

\section{2) Model Drill and Practice}

Kemampuan siswa pada mata pelajaran matematika dengan menggunakan model drill and practice pada setiap tahapan implementasi model dapat digambarkan seperti berikut:

\begin{tabular}{|c|c|c|c|c|c|c|c|c|c|c|c|c|c|}
\hline \multicolumn{14}{|c|}{ Paired Samples Statistics } \\
\hline & & \multicolumn{4}{|c|}{ Tahap III } & \multicolumn{4}{|c|}{ Tahap I } & \multicolumn{4}{|c|}{ Tahap II } \\
\hline & & $\begin{array}{l}\text { 蛋 } \\
\text { 号 }\end{array}$ & $z$ & 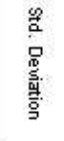 & 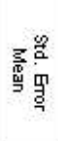 & 㺃 & $z$ & $\begin{array}{l}\frac{9}{2} \\
0 \\
0 \\
\frac{0}{5} \\
\frac{4}{5} \\
\frac{5}{3}\end{array}$ & 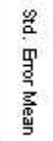 & $\begin{array}{l}\text { 胥 } \\
\text { 㟧 }\end{array}$ & $z$ & 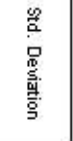 & 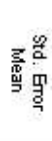 \\
\hline \multirow{2}{*}{$\begin{array}{c}\text { Pair } \\
1\end{array}$} & PRETES & 3.3250 & 40 & 1.1410 & .1804 & 2.8750 & 40 & 2.1145 & .3343 & 3.0250 & 40 & 1.9280 & .3048 \\
\hline & POSTES & 7.2750 & 40 & .7841 & .1240 & 7.4750 & 40 & .9604 & .1519 & 7.5750 & 40 & 1.1959 & .1891 \\
\hline
\end{tabular}


Rata-rata hasil belajar siswa SMK tahap I antara sebelum dilaksanakan proses pembelajaran berbasis komputer model drill and practice yaitu sebesar 3,33 dengan standar deviasi sebesar 1,14, sedangkan rata-rata setelah dilaksanakan proses pembelajaran berbasis komputer model drill and practice sebesar 7,28 dengan standar deviasi 0,78.

Rata-rata hasil belajar siswa pada tahap II antara sebelum dilaksanakan proses pembelajaran berbasis komputer yaitu sebesar 2,88 dengan standar deviasi sebesar 2,11 sedangkan rata-rata setelah dilaksanakan proses pembelajaran berbasis komputer model drill and practice sebesar 7,48 dengan standardeviasi sebesar 0,96.

Dari hasil perhitungan di atas, menunjukkan rata-rata keberhasilan belajar siswa sebelum dilaksanakan proses pembelajaran berbasis komputer model drill and practice pada tahap III yaitu sebesar 3,03 dengan standar deviasi sebesar 1,93 . Sedangkan rata-rata setelah melaksanakan proses pembelajaran berbasis komputer model drill and practice sebesar 7,58 dengan standar deviasi 1,19.

Rata-rata nilai yang diperoleh siswa pada setiap tahapan penelitian secara umum menunjukkan adanya kenaikan antara sebelum dan sesudah proses pembelajaran berbasis komputer model drill and practice. Kemudian dilihat dari standar deviasi yang menunjukkan kebervariasian kemampuan siswa antara sebelum dan sesudah proses pembelajaran berbasis komputer model drill and practice menunjukkan bahwa pemahaman siswa terhadap materi pelajaran ketika sebelum proses pembelajaran berbasis komputer model drill and practice lebih bervariasi. Hal ini dapat dipahami karena setiap individu memiliki kemampuan yang berbeda dengan yang lainnya.

Untuk melihat kebermaknaan proses pembelajaran berbasis komputer model drill and practice, maka dilakukan uji 
perbedaan. Melalui uji perbedaan ini akan diketahui ada tidaknya peningkatan nilai prestasi siswa yang diperoleh antara sebelum proses pembelajaran berbasis komputer model drill and practice dan sesudah proses pembelajaran berbasis komputer model drill and practice. Hasil perhitungannya adalah:

\begin{tabular}{|c|c|c|c|c|c|c|c|c|c|}
\hline \multicolumn{10}{|c|}{ Paired Samples Test } \\
\hline & & \multicolumn{5}{|c|}{ Paired Differences } & \multirow[t]{3}{*}{$\mathrm{t}$} & \multirow[t]{3}{*}{ df } & \multirow{3}{*}{$\begin{array}{l}\text { Sig. (2- } \\
\text { tailed) }\end{array}$} \\
\hline & & \multirow[t]{2}{*}{ Mean } & \multirow[t]{2}{*}{$\begin{array}{c}\text { Std. } \\
\text { Deviation }\end{array}$} & \multirow[t]{2}{*}{$\begin{array}{l}\text { Std. Error } \\
\text { Mean }\end{array}$} & \multicolumn{2}{|c|}{$\begin{array}{l}95 \% \text { Confidence Interval of } \\
\text { the Difference }\end{array}$} & & & \\
\hline & & & & & Lower & Upper & & & \\
\hline TAHAP I & $\begin{array}{l}\text { PRETES - } \\
\text { POSTES }\end{array}$ & -3.95 & 1.2184 & .1927 & -4.3397 & -3.5603 & 20.50 & 39 & .000 \\
\hline TAHAP \| & $\begin{array}{l}\text { PRETES - } \\
\text { POSTES }\end{array}$ & -4.60 & 1.5326 & .2423 & -5.0901 & -4.1099 & 18.98 & 39 &, 000 \\
\hline TAHAP III & $\begin{array}{l}\text { PRETES - } \\
\text { POSTES }\end{array}$ & -4.55 & 1.7387 & .2749 & -5.1061 & -3.9939 & 16.55 & 39 & .000 \\
\hline
\end{tabular}

Dari hasil perhitungan analisis variansi pada tahap I, diketahui bahwa hasil tes awal dengan akhir menunjukkan adanya perbedaan yaitu ditunjukkan oleh $t_{\text {hitung }}$ sebesar 20,50 dengan $p<0,001$. Artinya bahwa kemampuan siswa SMK Negeri pada implementasi mata pelajaran Matematika tahap I antara sebelum dan sesudah proses pembelajaran berbasis komputer model drill and practice menunjukkan adanya peningkatan yang signifikan.

Keberhasilan pelaksanakan proses pembelajaran berbasis komputer model tutorial juga ditunjukkan oleh perbedaan keberhasilan belajar siswa pada tahap II. Dari hasil analisis diketahui bahwa $t_{\text {hitung }}$ sebesar 18,98 dengan $p<0,001$. Artinya kemampuan siswa antara sebelum dan sesudah proses pembelajaran berbasis komputer model drill and practice pada mata pelajaran Matematika menunjukkan adanya perbedaan. Karena itu dapat dinyatakan bahwa program pembelajaran berbasis komputer model drill and practice efektif dilaksanakan.

Dari hasil perhitungan diperoleh gambaran bahwa $t_{\text {hitung }}$ sebesar 16,55 dengan $p<0,001$. Hal ini mengandung arti bahwa kemampuan siswa antara sebelum dan sesudah proses pembelajaran berbasis komputer model tutorial pada mata 
pelajaran Matematika tahap III di SMK Negeri menunjukkan adanya perbedaan. Artinya bahwa kemampuan siswa antara sebelum dan sesudah proses pembelajaran berbasis komputer model drill and practice menunjukkan adanya peningkatan yang signifikan. Gambaran perbandingan rata-rata nilai prestasi belajar siswa pada setiap tahapnya dapat dilihat pada tabel berikut.

Tabel 2. Perbandingan Hasil Belajar Matematika Siswa SMKN Pada Setiap Tahap (I, II dan III) Pembelajaran Berbasis Komputer Model Drill And Practice Pada Pelajaran Matematika

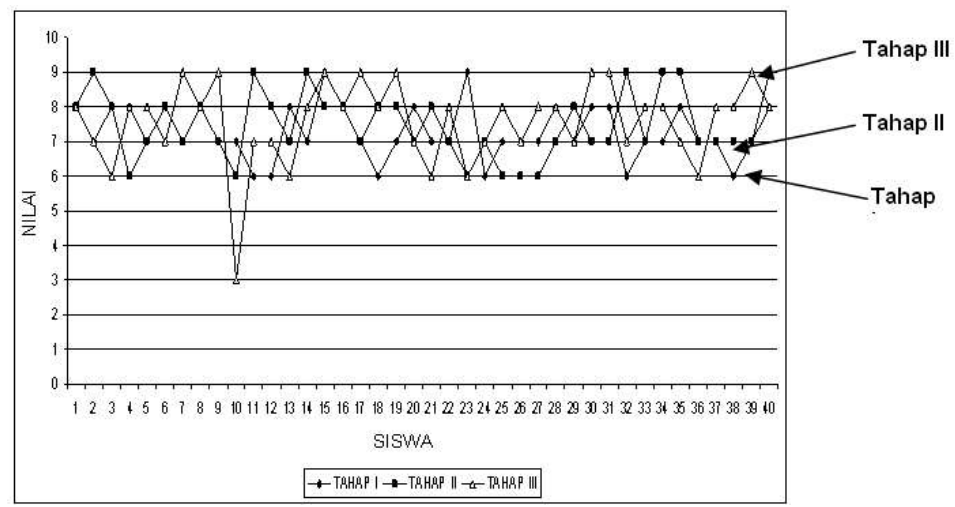

Ketiga, faktor-faktor yang mendukung pelaksanaan model pembelajaran berbasis komputer dalam meningkatkan kompetensi siswa pada mata pelajaran matematika di SMK yaitu adanya laboratorium komputer, adanya jaringan (LAN) sehingga, mempermudah pelaksanaan pembelajaran berbasis komputer, memiliki guru matematika yang kompeten dan antusias untuk mengembangkan model pembelajaran berbasis komputer, motivasi siswa yang tinggi untuk mengikuti pembelajaran berbasis komputer, dan Kepala Sekolah dan Pembantu Kepala Sekolah yang welcome, dan sangat apresiatif terhadap pengembangan pembelajaran berbasis komputer. 
Faktor-faktor yang menghambat pelaksanaan model pembelajaran berbasis komputer dalam meningkatkan kompetensi siswa pada mata pelajaran matematika adalah budaya mengajar kompensional yang merasa cukup puas dengan menggunakan metode ceramah, memerlukan tenaga khusus untuk mengembangkan Model Pembelajaran Berbasis Komputer, sehingga memerlukan biaya sedikit mahal, sangat tergantung pada adanya aliran listrik, memerlukan kerjasama antara ahli media/pemrograman dengan guru bidang studi, masih adanya anggapan guru yang kurang mau direpotkan dengan membuat atau menyediakan media pembelajaran interaktif, sangat tergantung pada adanya laboratorium, laboratorium digunakan untuk semua kelas secara bergiliran, belum adanya ahli teknologi pendidikan, hanya komputer untuk server yang pentium IV, sementara kliennya adalah cloning dari pentium I, sehingga jalanya agak lambat, ada kekhawatiran dari guru dan teknisi komputer bahwa pembelajaran berbasis komputer dapat menggantikan posisi guru, karena pada saat pelaksanaan pembelajaran berbasis komputer guru matematika hanya sebagai fasilitator saja.

Keempat, pembelajaran matematika berbasis komputer model tutorial ternyata lebih efektif jika dibandingkan dengan model drill and practice pada bahasan operasi bilangan berpangkat. Begitu juga jika dibandingkan antara pembelajaran berbasis komputer dengan pembelajaran konpensional yang berupa tatap muka, ternyata siswa terlihat lebih antusias dalam kegiatan pembelajarannya dengan menggunakan komputer, dibandingkan dengan tatap muka di kelas. Efektivitas model pembelajaran tutorial dan model drill dapat dilihat pada tabel berikut. 
Tabel 3. Perbandingan Hasil Belajar Siswa Pada Model Tutorial Dengan Model Drill And Practice Siswa Tahap III

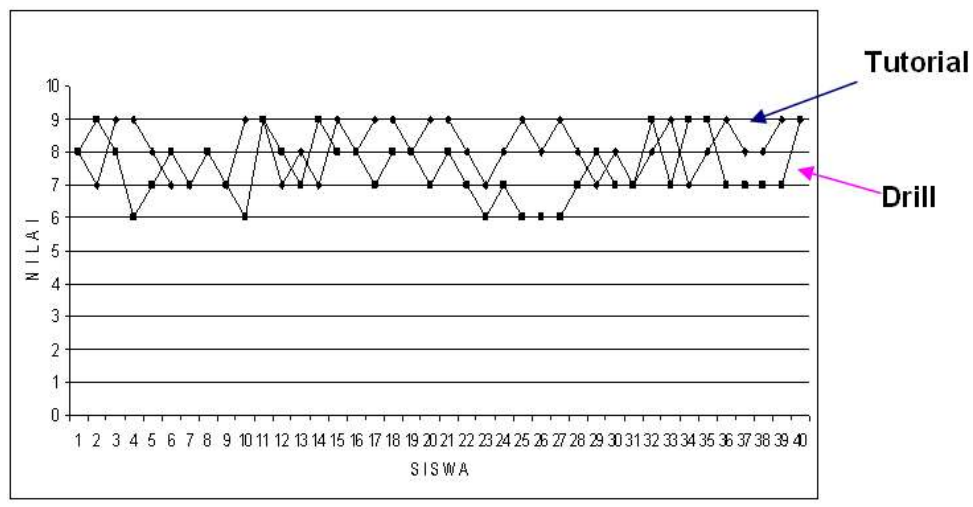

\section{KESIMPULAN}

1. Kondisi pembelajaran matematika di SMK yang dijadikan lokasi penelitian secara umum sudah berjalan baik, sebagaimana dapat dilihat dari:

a. Pemahaman guru matematika terhadap tujuan pendidikan matematika di SMK, secara umum sudah memahami tujuan yang dikembangkan dalam rencana pembelajaran.

b. Sumber yang digunakan guru dalam pembelajaran matematika cenderung masih tertumpu pada sumber belajar yang tersedia di sekolah (by utilization). Buku paket yang ada di sekolah dijadikan sebagai sumber utama, sedangkan penunjang yang digunakan adalah buku yang pada tahun-tahun sebelumnya digunakan.

c. Sarana yang digunakan guru dalam kegiatan pembelajaran matematika di SMK lokasi penelitian, terutama untuk menunjang pelaksanaan pembelajaran Matematika adalah tersedianya laboratorium komputer, ICT Centre, dan TV edu. 
d. Evaluasi yang dilakukan guru dalam pembelajaran matematika selama ini yaitu evaluasi pada setiap akhir bab (formatif) dan pada akhir semester (sumatif).

2. Pengembangan program pembelajaran berbasis komputer model tutorial dan dril and practice dalam meningkatkan kemampuan siswa secara umum dilakukan melalui tahap perencanaan pembelajaran, pelaksanaan pembelajaran dan evaluasi pembelajaran.

a. Perencanaan pengembangan model tutorial dan drill and practice yaitu: (1) model pembelajaran tutorial mengacu kepada komponen-komponen perencanaan pembelajaran yaitu: pengenalan, penyajian informasi, pertanyaan dan respon jawaban, penilaian respon, pemberian feedback tentang respon, pembetulan, segmen pengaturan pembelajaran, dan penutup; (2) model pembelajaran drill and practice, yaitu mengacu kepada komponen pencapaian pembelajaran sebagai berikut: penyajian masalah-masalah dalam bentuk latihan soal pada tingkat tertentu dari penampilan siswa; siswa mengerjakan soal-soal latihan; program merekam penampilan siswa, mengevaluasi kemudian memberikan umpan balik; dan jika jawaban yang diberikan siswa benar program menyajikan materi selanjutnya, dan jika jawaban salah program menyediakan fasilitas untuk mengulangi latihan (remidial) yang dapat diberikan secara parsial atau pada akhir keseluruhan soal.

b. Pelaksanaan Pembelajaran berbasis komputer pada model totorial dan drill and practice yaitu:

1) Tahap-tahap yang dilakukan dalam pelaksanaan pembelajaran model tutorial, yaitu: (a) tahap pengenalan (introduction) meliputi: penampilan judul program (title page) yaitu halaman judul yang dapat menarik perhatian siswa; menginformasikan tujuan 
pembelajaran atau kompetensi yang diharapkan (presentation of objective), meliputi standar kompetensi, kompetensi dasar dan indikator; menampilkan petunjuk penggunaan (direction); menampilkan stimulasi pengetahuan (stumulating prior knowledge); menampilkan inisial kontrol (initial student control), yaitu berupa button pilihan untuk siswa dalam menggunakan program; (b) Tahap penyajian informasi (presentation of information) meliputi: mode atau bentuk penyajian baik berupa teks, gambar, foto, image, dan sebagainya; panjang teks penyajian (length of text presentation), grafik dan animasi, penggunaan warna, dan penggunaan prompt; (c) tahap menampilkan pertanyaan dan respon jawaban (question of responses); (d) tahap penilaian terhadap respon/ jawaban siswa (judging of responses); (e) tahap pemberian balikan terhadap respon siswa (providing feedback about responses); (f) tahap pembenaran (remediation); (g) tahap segmen pengaturan pengajaran (sequencing lesson segment); (h) tahap penutup (closing), biasanya berupa ringkasan atau rangkuman materi yang telah disampaikan, dan menginformasikan materi/pokok bahasan yang akan dipelajari berikutnya, program dapat pula diakhiri dengan ucapan selamat dan terima kasih.

2) Tahap-tahap yang dilakukan dalam pelaksanaan pembelajaran model drill and practice, yaitu: (a) tahap pengenalan (introduction) yaitu berupa: penampilan judul program (title page) yaitu halaman judul, menyampaikan tujuan pembelajaran atau kompetensi yang diharapkan (presentation of objective), menampilkan petunjuk penggunaan (direction), menampilkan stimulasi pengetahuan (stumulating prior knowledge), menampilkan inisial kontrol (initial student control), yaitu berupa button pilihan untuk siswa dalam 
menggunakan program; (b) tahap penyajian informasi (presentation of information) berupa soal-soal latihan, meliputi: mode atau bentuk penyajian soal, baik berupa teks, gambar, foto, image, dan sebagainya; panjang teks penyajian (length of text presentation), grafik dan animasi. Program drill dapat menampilkan grafik dan animasi bila dipandang perlu. penggunaan warna, yaitu berhubungan dengan presentasi program baik berupa teks, grafik, gambar dan latar belakang, penggunaan prompt, yaitu adanya acuan yang digunakan untuk memandu, kemana dan bagaimana program ini dilakukan dan harus bagaimana selanjutnya; (c) tahap menampilkan pertanyaan dan respon jawaban (question of responses); (d) tahap penilaian terhadap respon/jawaban siswa (judging of responses); (e) tahap pemberian balikan terhadap respon siswa (providing feedback about responses); (f) tahap pengulangan (remediation); (g) tahap pengaturan pengajaran (sequencing lesson segment); (h) tahap penutup (closing), biasanya berupa ucapan selamat telah menyesaikan program drill and practice dengan baik yang diikuti dengan perolehan skor/nilai. Bila mencapai batas lulus, dapat langsung keluar, tapi bila belum mencapai batas lulus, siswa harus mengulang kembali.

c. Evaluasi pembelajaran matematika berbasis komputer pada model totorial dan drill and practice yaitu dilakukan pada awal proses pembelajaran (pre test), saat proses pembelajaran dan di akhir proses pembelajaran (pos test).

3. Faktor-faktor yang mendukung pelaksanaan model pembelajaran berbasis komputer dalam meningkatkan kompetensi siswa pada mata pelajaran matematika di SMK yaitu adanya laboratorium komputer, adanya jaringan (LAN) sehingga, mempermudah pelaksanaan pembelajaran berbasis komputer, memiliki guru matematika yang kompeten dan 
antusias untuk mengembangkan model pembelajaran berbasis komputer, dan motivasi siswa yang tinggi untuk mengikuti pembelajaran berbasis komputer.

4. Faktor-faktor yang menghambat pelaksanaan model pembelajaran berbasis komputer dalam meningkatkan kompetensi siswa pada mata pelajaran matematika adalah budaya mengajar kompensional yang merasa cukup puas dengan menggunakan metode ceramah, memerlukan tenaga khusus untuk mengembangkan Model Pembelajaran Berbasis Komputer, sehingga memerlukan biaya sedikit mahal, sangat tergantung pada adanya aliran listrik, memerlukan kerjasama antara ahli media/pemrograman dengan guru bidang studi, masih adanya anggapan guru yang kurang mau direpotkan dengan membuat atau menyediakan media pembelajaran interaktif, sangat tergantung pada adanya laboratorium.

5. Pembelajaran matematika berbasis komputer model tutorial ternyata lebih efektif jika dibandingkan dengan model drill and practice pada bahasan operasi bilangan berpangkat. Begitu juga jika dibandingkan antara pembelajaran berbasis komputer dengan pembelajaran konpensional yang berupa tatap muka, ternyata siswa terlihat lebih antusias dalam kegiatan pembelajarannya dengan menggunakan komputer, dibandingkan tatap muka di kelas.

\section{DAFTAR PUSTAKA}

Ali, Mohammad. (2005). E-Learning in the Indonesian Education System. p1524. Asia-Pacific Cyber Education Journal, Vol, 1 No. 2. Korea: Institute Of APEC Cyber Education.

Alessi, Stephen M \& Trollip Stanley R. (1985). Computer Based Instruction. New Jersey: Prentice-Hall.Inc.

Borg R, Walter and Gall, Meredith Damien. (1979). Educational Research. New York: Longman Inc. 
Bacon (1992). Computer In Teaching of Physic. Computer and Education, an International Journal, Vol. 19(1/2). Britain: Pergamon Press. Ltd.

Bruce Joyce et al. (2000). Models of Teaching Fifth Edition. Boston: Ally \& Bacon.

Crisswel, Eleanor L. (1989). The Design of Computer Based Instruction. New York: Macmillan Publishing Company.

Hamalik, Oemar. (1993). Evaluasi Kurikulum. Bandung: Rosdakarya.

Hermawan, Asep Herry, Rusman, Deni D. (2005). Pengembangan Model

Pembelajaran Berbasis Komputer (Teori dan Praktek). Bandung: Publikasi Jurusan Kurtek FIP

Heinich, et.al. (1985). Instructional Media \& New Technology of Instruction.

New York: MacMillan Publishing.

Hisham, Badrul. (2001). Kesediaan Guru dalam Pengajaran dan Pembelajaran

Matematik Berbantukan Komputer (PPBK) di Sekolah Menengah. Tersedia: http://ww.kdp.ppk.my/kuritem.htm

Ibrahim, R. \& Kayadi, B. (1994). Pengembangan Inovasi dalam Kurikulum. Jakarta : UT, Depdikbud.

Munir dan Zaman, Halimah Badioze. (2001). Metodologi Pengembangan Multimedia dalam Pendidikan (Studi Kasus terhadap Proyek: Multimedia In Education for Literacy (MEL), Universiti Kebangsaan Malaysia. Mimbar Pendidikan, No. 2 tahun XXI. Bandung: UPI.

Print, M. (1993). Curriculum Development and Design. Second Edition. Sydney: Allen \& Unwin.

Rusyana, A. (1998). Penerapan Model Mengajar Berbasis komputer dengan menggunakan pendekatan Analogi sebagai upaya meningkatkan prestasi belajar siswa melalui pengajaran Biologi. Tesis:Tidakan dipublikasikan. Bandung: IKIP Bandung.

Ruseffendi. (1980). Dasar-dasar Matematika Modern dan Komputer untuk Guru. Bandung: Tarsito.

Rusman, (2003), Model-Model Pembelajaran Berbasis Komputer, Jurusan Kurikulum dan Teknologi. Makalah. Tidak Diterbitkan.

Syaodih Sukmadinata, Nana. (2000). Pengembangan Kurikulum Teori dan Praktek. Bandung: Remaja Rosdakarya.

Shute \& Grendell. (1994). What does The Computer Contribute to Learning? Dalam: Computer and Education, an International Journal, Vol. 23. Britain: Pergamon Press, Ltd. 